\title{
АКТУАЛЬНІ ВИМІРИ ВИВЧЕННЯ ПРАВОСЛАВНОГО СПІВАЦЬКОГО МИСТЕЦТВА: ВІД ПРАГМАТИКИ БОГОСЛУЖІННЯ ДО СУЧАСНИХ ХУДОЖНІХ РІШЕНЬ
}

Осадча С. В.

\section{ВСТУП}

Стан сучасної культури, а також стан сучасного гуманітарного знання зумовлюють необхідність обговорення низки питань, пов'язаних із сучасними художніми проявами та визначенням статусу православного співацькою мистецтва. Як для традиційної мистецтвознавчої та музикознавчої літератури, так і для богословськотеологічних досліджень такий ракурс вивчення та пов'язаний із ним поняттєвий комплекс усе ще залишаються новим, мало засвоєним. Аналогічна ситуація складається в безпосередньому системному засвоєнні цієї традиції як академічної дисципліни, адже вона існує в зазорі між релігійною та світською сферами знання, частково ініціюється кожною з них, але ні до однієї з них не належить до кінця. Отже, на першому етапі свого формування явище православного співацького мистецтва виявляє перехідність, а також існування різних, множинних підходів до нього.

Окремим виявляється питання про входження православного співу в музичну культуру, тобто про те, якою мірою можна православну богослужбову традицію розглядати як частину музичної культури. А це означає, що предметом уваги стає й сама музична культура як категорія, яка може наповнюватися різними понятійним значеннями, тлумаченнями цих значень. 3 іншого боку, православний спів $\epsilon$ історично і структурно-семантично завершеним, цілісним культурним явищем, що відтворює й розвиває домінуючі моральні й естетичні тенденції культури.

\section{1. Специфіка історичного формування православного богослужбово-співацького мистецтва}

Початок розквіту християнського православного богослужіння й пов'язане 3 ним формування спеціального корпусу текстів, розвиток обрядової сторони богослужіння пов'язаний із діяльністю імператора Костянтина Великого, адже саме в період його правління, згідно 3 Міланським едиктом (313р.), християнство займає місце офіційної 
державної релігії. Із цього моменту починається активний розвиток усіх видів церковних мистецтв, будівництво величних храмів, удосконалення богослужбового чинопослідування, поява значної кількості нових молитвослівних текстів і міцний поштовх у розвитку богослужбового співу ${ }^{1}$. Основні принципи християнської культури в найбільш повному вигляді сформувалися в Візантії, що й виражено в візантійському мистецтві. У розвитку богослужбової практики 3 моменту звернення імператора Костянтина можна виділити кілька напрямів, завдяки яким починається розквіт усіх видів храмових мистецтв:

1) розвиток та ускладнення зовнішньої церемоніально-обрядової сторони богослужіння, пов'язаної передусім чергу 3 розвитком храмобудування;

2) ускладнення «літургійних» кіл (церковного року, седмиці й добового богослужбового кола), виникнення нових свят і цілих циклічних святкових комплексів, нових служб;

3) швидке зростання гімнографії, що стає поступово головним елементом богослужіння;

4) виникнення та розвиток різних шкіл церковного мистецтва.

Еволюцію цих процесів о. Олександр Шмеман слідом за M. Скабаллановичем розділяє на кілька періодів, а саме IV-V століття розглядаються як епоха «бурхливого «цвітіння» й пов'язаних із ним глибоких змін у богослужбовому житті Церкви» ${ }^{2}$; 3 VI по VIII століття - епоха поступової стабілізації та впорядкування нових культових форм; нарешті, починаючи з IX століття - епоха остаточного завершення формування богослужіння «візантійського» типу, досягнення нею теперішнього вигляду.

Разом із тим, як указує о. Олександр Шмеман, будь-яка із зазначених ліній розвитку богослужіння не має свого абсолютного початку в епоху Костянтина Великого - не $\epsilon$ наслідком викликаного ним перелому в історії Церкви. Усі зміни були так чи інакше підготовлені попередньою епохою, хоча не залишає ніяких сумнівів той факт, що «костянтинівський світ» (поняття о. Олександра Шмемана) дав потужний поштовх i прискорив процеси формування

${ }^{1}$ Гарднер И. Богослужебное пение Русской Православной Церкви. История. Сергиев Посад: Московская духовная академия, 1998. Т. II. 640 с.; Мартынов В. История богослужебного пения : учебное пособие. Москва : РИО Федеральных архивов; Русские огни, 1994. 240 с.; Матвеев Н.В. Хоровое пение. История русского церковного пения. Электросталь : Издательство братства во имя святого князя Александра Невского, 1998. 287 с.; Трубин Н. Духовная музыка. Смоленск : Смоленское областное книжное издательство «Смядынь», 2004. 229 с.

2 О. Александр Шмеман. Введение в литургическое богословие. СанктПетербург : Библиополис, 2006. С. 81. 
богослужбової та культурної традиції. Головним досягненням Костянтинівській епохи багато дослідників-літургістів уважає свободу культу, яку отримала Церква завдяки міланському едикту.

У зв'язку з цим було б важко заперечувати глибокі зміни, якими відзначена літургічне життя Церкви, починаючи з епохи Костянтина, разом із тим у багатьох історичних дослідженнях, як указує о. Олександр Шмеман, численні пояснення того, у чому полягала ця зміна, виявлялися часто неправильними або неповними, тому що виходили з неправильної історичної перспективи. У них позначилася обмеженість того методу вивчення історії богослужіння, яку о. Олександр Шмеман визначав як «літургійний формалізм». Цей метод, на думку Шмемана, зводить усе вивчення історії богослужіння до аналізу літургійних текстів, до класифікації різних «літургійних родин» i їx підрозділів, до вивчення їх впливу один на одного тощо. Але християнське богослужіння не розвивається «в будь-якому безповітряному, ізольованому від усіх інших сторін церковного життя, просторі» ${ }^{3}$. Одним із найголовніших чинників цього розвитку Шмеман уважає властиву кожній епосі релігійність, або «релігійне почуття», яке змінюється від епохи до епохи ${ }^{4}$.

Іншими словами, об'єктивний зміст релігії, яке ми можемо виявити в іiї «офіційних» вираженнях (догматі, культі тощо), може по-різному сприйматися й переживатися релігійною громадою кожної окремої епохи - залежно від різних іiі культурних, духовних і соціальних особливостей. Цей «коефіцієнт заломлення» (Шмеман) і визначає собою «релігійність», або релігійне почуття, а це останнє, у свою чергу, впливає на подальший розвиток самої «релігії» в її об'єктивному змісті.

Особливо показовим i важливим при вивченні еволюції християнського співацького мистецтва вказана вище іманентна якість співочого боку богослужіння, завдяки якій це релігійне почуття виражається найбільш явно. Шмеман визначає цю релігійність або релігійне почуття як літургійне благочестя, а о. Павло Флоренський визначає людину, що має подібні якості, як «людину літургійну». Отже, «коефіцієнт заломлення» - це психологічне сприйняття культу, його переживання в релігійному почутті, його переломлення у свідомості віруючих.

Дуже важливо, що ще в ранньохристиянські часи, ще в апостольських Посланнях і постановах можна знайти досить докладні вказівки на те, що належить співати християнам на молитовних зборах

3 О. Александр Шмеман. Введение в литургическое богословие. СанктПетербург : Библиополис, 2006. С. 85

${ }^{4}$ Там само. 
і як саме має розумітися й відбуватися богослужбовий спів. Так, Апостол Павло говорить про увагу до духовного стану співака, про необхідність особливого його зосередження: «Исполняйтеся Духом, глаголюще себе во псалмех и пениих, и песнех духовных, воспевающе и поюще в сердцах ваших Господеви» (церк.-слов.) (Еф. 5, 19); також відоме висловлювання, яке має стосунок до характеру та особового настрою співу «Вся же благообразно и по чину да бывают» (церк.-слов.) (1 Кор. 14, 40).

Свідоцтво турбот про поширення й систематизацію співу знаходимо й у так званих «Апостольських постановах». Так, у кн. II, гл. 57 сказано: «... після двох читань із (старозавітних) книг будь-хто інший нехай співає псалми Давида, а народ нехай повторює голосно кінці віршів» ${ }^{5}$. Фактично це були встановлені ще в апостольські часи перші жанрові різновиди піснеспівів, які є обов'язковими для виконання від час богослужіння, а саме псалми Давида, що становили ще в євреїв самий уживаний різновид духовних піснеспівів; по-друге, співи або, за грецьким оригіналом, гімни; по-третє, пісні духовні.

Період часу Вселенських соборів (з IV-VIII) стає найбільш плідним етапом для розвитку християнської культури, що значно вплинуло на церковно-співочого боку богослужіння. Важливим для вивчення богослужбової-співочої традиції стає iї розгляд не тільки як особливої галузі мистецтва, а й ще як аскетичної дисципліни, що зумовлює унікальний шлях розвитку богослужбового співу на стику між богослов'ям і мистецтвом.

Найбільш важливим аспектом в естетиці християнської культури, що формується в цей період, стає ідея божественної, абсолютної краси, «істинно прекрасного». Великі кападокійські мислителі, а саме Василь Великий, Григорій Ніський, Григорій Богослов у працях багато уваги приділяли поясненню важливості розуміння ідеї божественної краси «Невиречений повністю й неописаний блискавичний прояв Божественної краси; ні слово не може висловити цього, ні слух вмістити» ${ }^{6}$.

Отже, 3 IV століття в галузі богослужбового співу відбуваються значні зміни в бік систематизації та впорядкування вже чинних традицій, з одного боку, з іншого - бурхливий розквіт нових форм і правил. Отже, питання про формування православних текстів у єдності їх ритуально-прагматичної, молитвослівної та співочої сторін

\footnotetext{
${ }^{5}$ Никольский А. Краткий очерк истории церковного пения в период $\mathrm{I}-\mathrm{X}$ веков. О иеерковном пении : сборник статей. Москва : Лодья, 2001. С. 27-62.

6 Добротолюбие избранное для мирян. Москва : Изд. Сретенского монастыря, 2010. 352 c.
} 
$\epsilon$ взаємозумовленими 3 питаннями про історичну періодизацію православного співу. 3 іншого боку, формування православної співочої системи відбувається на основі богослужбового канону, ініційованого ритуальною дією і словом, тобто на основі канону як принципу організації текстового цілого православного чинопослідування.

Головною особливістю співу перших століть стає те, що творці текстів і мелодій пісенеспівів були богословами в прямому сенсі слова, зумівши висловити в слові та звуці особистий досвід богоспілкування і квінтесенцію церковного віровчення. Тому треба визнати вдалими й справедливими слова сучасного дослідника, які стосуються знаменного розспіву, але їх повністю можна віднести й до більш ранніх часів існування християнської богослужбової традиції: «... знаменний спів створювався в процесі чернечого подвигу, $\epsilon$ результатом праведного життя й, у свою чергу, сам спонукає до праведного життя ${ }^{7}$.

Архімандрит Кіпріан (Керн) уважав, що «богословський підхід до науки про богослужіння, тобто прагнення побудувати літургійне богослов'я й систематизувати богословські ідеї нашого богослужіння, звертає увагу головним чином на внутрішній зміст богослужбового матеріалу. А так як він міститься переважно в богослужбових співах або в гімнографії, то вивчення цієї останньої становить для дослідника православного богослужіння особливий інтерес. Це вивчення має відбуватися, звичайно, в історичній перспективі, чому історія співів, їх розвиток і припинення тих чи інших форм їх, так само як й історія піснеспіваків, стоїть у центрі нашої уваги» ${ }^{8}$. Дослідження гімнографічної спадщини актуалізує кілька підходів, залежно від яких воно набуває того чи іншого характеру. Серед цих підходів варто вказати історико-археологічний, ритуалістичний (термін архімандрита Кіпріана Керна), статутний або богословський. Основою гімнографічної спадщини православної церкви $\epsilon$ тексти Святого Письма, Старого і Нового Завітів, а також творчість церковних авторів, тексти яких $є$ багатим і надзвичайно великим матеріалом, примітною особливістю якого стає різноманітність гімнографічних форм.

Вивчення різних аспектів формування гімнографічних форм i богослужбових співацьких традицій не можна вважати достатньо завершеним без уваги до принципів і способів відтворення тексту богослужіння. Суворо кажучи, у богослужбовій практиці Православної

7 Кутузов Б. Возрождать ли нам знаменный распев? Журнал Московской Патриархии. 1993. № 3. С. 69.

${ }^{8}$ Архимандрит Киприан (Керн). Литургика. Гимнография и эортология. Москва: Крутицкое Патриаршее Подворье, 1999. С. 21. 
церкви елемент «говоріння» $є$ повністю відсутнім, адже в службовій практиці всі тексти «проспівуються» 3 тією чи іншою мірою свободи.

Структура богослужіння й різні літургійні функції співацькі піднесеного слова зумовлюють різні види виконання текстів, які мають у різних національних частинах Православної церкви низку споріднених рис або можуть бути практично ідентичними. Деякі із цих видів, як указує I. Гарднер у теоретичних працях, є близькими й літургічними взірцям Західної церкви, що є доказом їх старовини. Однак музичні форми виконання, співочий компонент богослужіння мають власне функціональне призначення в богослужінні, яке вказується та регулюється Типіконом, і хоча в окремих випадках можуть бути деякі відхилення (і навіть зміни) від указівок Типікону, але загальний принцип залишається незмінним.

Співоче проголошення слова в богослужінні можна розділити на дві великі групи: поодиноке (тобто одним читцем або одним співаком) виконання частини богослужіння та колективне (колективом співаків). Грунтуючись на визначенні І. Гарднера, можна визначити такі градації в співочому компоненті богослужіння:

- псалмодія, яка характеризується постійною висотою тону, невизначеною мензуральною тривалістю окремих складів, протяжністю висоти тону, з імовірним відхиленням від постійної висоти тону тільки в кінці читання, відсутністю ясного ритму й динамічних коливань;

- екфонетика, де витримується постійна висота тону з імовірними відхиленнями в кінці фрази, що проявляється в більш виражених інтервальних ходах. При необхідності $є$ присутнім деяке розтягнення тонів, але без яскраво вираженого ритму, можливі невеликі динамічні коливання;

- cniв як вища градація співочого елемента богослужіння, що має значну структурно-композиційну та художню свободу 9 .

Читання на одному тоні, найбільш спрощене зі співочого погляду проспівування богослужбового тексту, й урочистий багатоголосний спів двох або декількох великих хорів - це два полюси, між якими $\epsilon$ багато поступових переходів, які, однак, тісно пов'язані один із одним і є одним єдиним співочим текстом богослужіння.

Підсумовуючи сказане, підкреслимо, що гімнографія, як історія і теорія гімнографічних форм, $\epsilon$ одним із найбільш цікавих i перспективних 3 музикознавчого боку напрямів у дослідженні богослужбових текстів, яке дає змогу по-новому поглянути на всю літургійну спадщину, зібрану протягом майже двох тисячоліть.

${ }^{9}$ Гарднер И. Богослужебное пение Русской Православной Церкви. Сущность. Система. История. Сергиев Посад : Московская духовная академия, 1998. Т. 1. С. 80. 
Гімнографічні тексти розподіляються по частинах у різних богослужбових книгах, а саме в Октоїху, Тріоді Пісної і Тріоді Квітній, Мінеях тощо. Вивчення кожної із цих книг пов'язане 3 особливим колом наукових проблем, а саме: 3 часом складання текстів, списком передбачуваних авторів, змістом текстів, їх співочою інтерпретацією. На відміну від світських поетичних текстів, богослужбова поезія обов'язково передбачає іï проспівування 3 тією чи іншою мірою свободи, про що говорилося вище. Тому вивчення богослужбової гімнографії, на відміну від вивчення інших літературних текстів, включає в себе не тільки саму структуру текстів, а і їх співочу сторону, у нерозривній єдності з якою ці тексти створювалися. У цьому полягає особливість вивчення гімнографії як специфічної дисципліни в колі сучасних музикознавчих курсів: вона вимагає, крім музикознавчої підготовки, знання літургіки, літературознавства, лінгвістики й безпосередньої практики церковного співу.

Без останньої уявлення про гімнографію буде усіченим, неповним або навіть спотвореним. Тільки при такому комплексному підході вивчення гімнографічної творчості дасть змогу повною мірою розглянути весь обсяг цього явища, включаючи різні його рівні, у тому числі рівні циклізації. Циклічність є загальним принципом системоутворення в православній традиції, який визначає, з одного боку, стійкість зовнішніх кордонів, 3 іншого $-\epsilon$ головною комунікативною властивістю цієї традиції. Фіксація й упорядкування функціонування гімнографічного складника як головного структурного компонента, а також циклічності як фактору динаміки традиції реалізується в Статуті (Типіконі) та поряд із ним знаходить фіксацію в Церковному Переданні.

Під Церковним Переданням часто розуміють трактування усного вчення Христа, що не має викладення в письмовому вигляді, а також фіксований в усній практиці живий досвід церковний. В. Лоський писав: «Передання є життям Святого Духа в Церкві» ${ }^{10}$. Разом із тим, на думку єпископа Каллиста (Уера), справжня і щира вірність церковному православному минулому «повинна бути творчою вірністю» ${ }^{11}$. Іншими словами, справжнє православ'я не може лише зводиться до повторності будь-яких формул, якими б давніми й історично виправданими вони не були: «... вірність Переданням, правильно зрозуміла, не механічний, пасивний та автоматичний процес передачі деякої мудрості, C. 61-76.

10 Лосский В. Предание и предания. Журнал московской патриархии. 1970. № 4.

${ }^{11}$ Епископ Каллист (Уэр). Внутренний смысл Предания. Предание и Церковь: от смысла к вечности. Роль Священного Предания в Православной Церкви / сост. А. Баранов. Москва : Образ, 2007. С. 7. 
запозиченої 3 віддаленого минулого» ${ }^{12}$. Для розуміння Передання зовсім недостатнім виявляється вивчення шляхом визнання його віровчительної системи, якщо при цьому той, хто вивчає, залишається за рамками традиції. Передання можна зрозуміти тільки лише перебуваючи всередині традиції, «православний мислитель повинен бачити Передання зсередини, повинен проникнути в його внутрішній дух, знову пережити його смисл так, щоб це переживання стало відкриттям, виповненим відваги і творчої уяви» ${ }^{13}$.

Тому повністю зрозумілою стає помилковість уявлення про непотрібність творчого, живого осмислення й переживання Передання. Ці уявлення прихильників «охоронного Православ'я» якраз перешкоджають цілісному розумінню святоотцівської спадщини й церковного Передання, адже головне завдання полягає якраз у творчому осмисленні попереднього досвіду з позиції сучасності, тобто не тільки зробити віру справді «святоотцівською», а й уміти висловлювати ії мовою, доступною людині XXI століття.

Пізнання «Відвертої Істини» (В. Лоський) має відбуватися не як пізнання мертвої букви, а як пізнання і прийняття «живого слова», причому прийти до неї можна, як уважає філософ, перебуваючи в Церкві, через прийняття таїнств та участь у богослужінні ${ }^{14}$. Передання, як пише В. Лоський, не варто шукати серед знань, що знаходять своє чітке визначення в слові, скоріше, його можна окреслити як зону мовчання: «... якщо ж ми хотіли б... протиставити Передання всьому, що передається реальністю слова, то треба сказати, що Передання - це мовчання» ${ }^{15}$. Святий Василій Великий говорив саме в цьому сенсі про «Передання»: «Та тьма, якою користується Святе Письмо, теж рід мовчання; щоб смисл учення - для користі тих, хто читає, розумівся без легкості» 16 . Іншими словами, свого роду «замовчування» Святого Письма від нього невіддільне, адже воно відтворюється й передається разом зі словами Писання, стаючи тією самою необхідною умовою його сприйняття. Отже, як указує В. Лоський, можна зробити висновок, що Передання можна певною мірою протиставляти Писанню, а також

${ }^{12}$ Епископ Каллист (Уэр). Внутренний смысл Предания. Предание и Церковь: от смысла к вечности. Роль Священного Предания в Православной Церкви / сост. А. Баранов. Москва : Образ, 2007. С. 7.

${ }^{13}$ Там само.

14 Лосский В. Предание и предания. Журнал московской патриархии. 1970. № 4. C. $61-76$.

15 Там само.

${ }^{16}$ Св. Василий Великий. Творения. Полное собрание творений Святых Отциов Церкви. Николаев : Сибирская Благозвонница, 2010. Т. 2. С. 189. 
не можна представляти одне без іншого, тим більше замінювати одне іншим; це дві, відмінні одна від одної реальності.

Отже, розуміння і прийняття Передання можливе лише шляхом його творчого осмислення й переживання, у такому випадку Передання постає не як якийсь статичний i незмінний елемент православного культу, а як динамічний процес переживання церковного досвіду, що стає причиною того, що Передання постійно доповнюється новими елементами, при цьому не втрачаючи того змісту, який був накопичений $з$ моменту виникнення християнства.

\section{2. Стильові основи вивчення богослужбово-співацької традиції}

Однією з домінуючих тенденцій культури кінця ХІХ - початку XX i кінця XX - початку XXI століть, що й зближає ці епохи у великому історичному часі, стає прагнення до переосмислення багатьох соціальних, у тому числі релігійних, цінностей. На рубежі $\mathrm{XX}-$ XXI століть діалогічна взаємодія світського, мирського («профанного») i релігійного, церковного («сакрального») типів свідомості стає ще більш активною, але, скоріше, 3 «логікою зворотності»; у зв'язку 3 новою популярністю й соціальною ангажованістю релігійної й навіть богослужбової тематики у світському мистецтві стає можливою втрата символіки як «теплоти гуртуючої таємниці» (С. Аверинцев), що повинна бути невід'ємною частиною всього, що пов'язано й богослужінням.

Розкриття цієї проблеми нинішнього стану церковного мистецтва, його стильових визначень надзвичайно важливо для розуміння сучасного становища православної культури у світі, але пов'язане 3 широким колом досліджень взаємодії церковного й світського типів культурної свідомості від початку християнства й до наших днів. 3 іншого боку, саме досвід музичної творчості дає змогу висвітлювати вузлові моменти цієї проблеми й показувати продуктивні шляхи іiі рішення.

Проблема збереження й передачі духовного досвіду - як досвіду створення ціннісного фундаменту культури - у руслі смислового самовизначення та своєрідного «виправдання» людського буття стає однією 3 центральних і найбільш затребуваних на сучасному етапі. У зв'язку із цим посилений інтерес викликають усі різновиди православного богослужбового співу, їх відродження та «нове життя» в сучасному композиторському й виконавському середовищі, а також помітна активізація музично-співацького життя православного храму. Однак досліджень, пов'язаних із систематичним підходом як до богослужбово-співацької традиції, так і до релігійно-храмової культури загалом, тим більше в іï історичній динаміці й у симультанному 
соціоестетичному вимірі все ще явно недостатньо. Тому вагомого значення набуває залучення до вивчення традиційної храмової культури теоретичних узагальнень провідних гуманітарних діячів, серед яких важливими стають праці М. Бахтіна, що дає можливість визначити стильову спрямованість проаналізованого матеріалу.

Сьогодні тема стильових основ православної культури, у тому числі й співацької, стала настільки актуальною, що породила надзвичайну строкатість, еклектичність в оцінках цього явища. Хоча справедливості заради треба сказати, що співацька культура Православної церкви на початку XX століття викликала не меншу полеміку й суперечки. Але тут варто зазначити, що богослужбовий спів початку XX століття й кінця ХХ століття - культурні феномени, що помітно відрізняються, хоча й пов'язані спільністю музично-інтонаційних джерел, «пам'яттю» жанру.

Якщо на початку XX століття духовну співацьку культуру характеризувало прагнення відродити самобутню співацьку культуру предків, знайти втрачені древні мелодійні пласти, то ХХ століття, завершуючись, намагається «реанімувати» не тільки давно збігле минуле, але й зовсім недавній відрізок часу, що підніс православну культуру на якісно новий професійний рівень. Якщо на початку ХХ століття, як висловився О. Гречанінов, «пробивали пролом» у корпусі культури, то наприкінці XX - початку XXI століть пролом зашпаровують, намагаючись відновити те, що втрачено, i водночас побачити можливість створення нового.

Петро Ілліч Чайковський був одним із перших представників професійних світських композиторів, який порушив питання про наявність ознак «церковності», «храмовості» піснеспівів, що вживалися в богослужінні. Свою позицію П. Чайковський висловив у листі, адресованому ректорові Київської духовної академії, у якому він писав: «Не входячи в історичні подробиці, коротенько скажу лише, що внаслідок фатального збігу обставин у нас із кінця минулого століття встановився нудотно-солодкуватий стиль італійської школи музики XVIII століття, що не задовольняє, на мою думку, узагалі умови церковного стилю, але особливо не споріднений духу й ладу нашого православного богослужіння. Це тим більше сумно, що до нас дійшли корінні наспіви давньоруської церкви, що носять у собі всі елементи не тільки загальної музичної краси, а й зовсім самобутнього церковномузичного мистецтва» ${ }^{17}$.

Отже, П. Чайковський актуалізує проблему храмовості й ставить питання про церковний стиль, що $є$ необхідною умовою існування та

17 Чайковский П. Письмо ректору Киевской духовной академии о состоянии церковного пения. 1882. URL: www. penie.mrezha.ru/pismochaj. 
функціонування богослужіння як єдиного організму. При цьому він уважав зовсім неможливим i неприпустимим ставлення до богослужбового співу як до виокремленої галузі богослужіння, у якій можливі та припустимі будь-які художні засоби та прийоми. Іншими словами, П. Чайковський уважав украй неправильним використання стін храму як свого роду «концертної сцени», на якій можливе виконання будь-яких вільних творів на духовну тему.

Композитори кінця XIX - початку XX століття, надаючи винятково вагомого значення смисловій та інтонаційній єдності, однорідності служби, уживають низку спроб створення не збірника окремих пісень, а єдиного циклічного твору. На цьому шляху, як відзначав O. Нікольский, першим був П. Чайковський: «Він перший із композиторів написав повну літургію, де рішуче все, що повинен виконувати хор, покладено на музику, тобто не тільки найголовніші пісні, як у колишніх авторів, а й усі єктенії, усі короткі молитвослів'я, усі відповіді кліру на вигуки священнослужбовців» ${ }^{18}$.

Загалом взаємодія двох жанрових систем музики (культової i світської) зумовлює формування нової жанрової галузі, що заслуговує на назву сакральна музика (термін Н. Гуляницької). Світська хорова традиція в процесі історичного розвитку починає претендувати на височину й глибину, сакралізованість образного змісту, які характерні для храмової традиції. Якщо церковна хорова музика межі століть спрямована на пошук індивідуалізованих стильових рішень, пошук свого авторства, то світська хорова музика виявляє тенденцію до універсальних стильових рішень, де композиторська індивідуальність підкоряється авторитету жанру. Починання П. Чайковського продовжено багатьма церковними композиторами не тільки в жанрі літургії й всенощного бдіння, а й в інших літургійних жанрах.

В історичній еволюції богослужбового співу існує власний стильовий діахронічний порядок: період панування одного співацького стилю змінюється іншим, витісняючи попередній практично повністю. Причому внутрішні границі стильового розвитку богослужбового співу представляються досить примітним явищем. У низці випадків розрив між зникаючим i зародженим стилями настільки великий, що припустити цю зміну закономірною, зумовленою процесом еволюції практично неможливо ${ }^{19}$. Інакше кажучи, такий стильовий стрибок

18 Никольский А. П.И. Чайковский как духовный композитор. Музыкальная жизнь. Москва, 1990. № 9. С. 14.

19 Аверинцев С. Поэтика ранневизантийской литературы. Санкт-Петербург : Азбука-классика, 2004. 480 с.; Лихачев Д. Поэтика древнерусской литературы. Москва : Наука, 1979. 360 с.; Успенский Н. Древнерусское певческое искусство. Москва : Музыка, 1965. 216 с. 
видається скоріше наслідком якогось «вибуху», повної трансформації соціальної психології й особистісної свідомості, і саме співацька, тобто музична, сторона здатна найбільше виразно виявити та відобразити це перетворення. Але всякого роду зміни, унесені завдяки динамічному процесу розвитку людської свідомості, стосуються виключно співацької сторони: канонічні тексти за весь історичний час із часів Візантії практично не зазнали змін.

Цю особливість християнського богослужіння відзначав Егон Велес, коли вказував, що, за винятком декількох пісень, гімнів, які додалися після фіксування чинопослідовування Літургії, духовна поезія практично не зазнала змін, але музичний розвиток не міг бути зупинений. Уже візантійські гімнотворці прикрашали мелодії, що супроводжували написані у віршованій формі або в поетичній прозі духовні поеми. Це відбувалося доти, поки не виникла необхідність скоротити музичні тексти, тому що в багатьох випадках прикраса музики унеможливила розуміння богослужбового тексту ${ }^{20}$. I в цьому випадку, і в наступній еволюції літургічного співу всі зміни стосувалися виключно музичної сторони, залишаючи при цьому богослужбові словесні тексти незмінними.

Кінець XX - початок XXI століття характеризується багато в чому полярними явищами. Так, сьогодні ми можемо спостерігати одночасне (синхронне) існування всіх тих співочих стилів богослужбового співу, які раніше змінювали один одного. Отже, співочі шари, взаємодія яких мала раніше «горизонтальне» вираження, підкорялося принципу спадкування або зміни одного одним, у сучасній духовній культурі утворюють нові зв'язки у «вертикальному» вимірі культури. Співіснують та активно розвиваються такі, здавалося б, несумісні плини, як знаменний і багатоголосний спів, причому як монодичний, так і поліфонічний спів одержують широкий резонанс у церковноспівацькій практиці.

На початку XXI століття стають майже регулярними різні творчі заходи, присвячені проблемам знаменного розспіву, на яких мова вже йшла не стільки про те, які існують проблеми вивчення знаменного співу з наукового погляду (як було це на початку XX століття), скільки про актуальні соціально-прагматичні аспекти, прикладні функції знаменного співу. У цей час можна говорити вже не про спроби відродити знаменний розспів, цей шлях уже значною мірою пройдений, чому свідченням слугують кількість хорових колективів, у чиїх репертуарах представлений виключно знаменний розспів, а також

${ }^{20}$ Wellesz E. A histori of Byzantine music and himnografhy. Oxford : At the Clarendon press, 1949. 358 p. 
церкви, у яких під час богослужіння звучить саме він. Сьогодні варто говорити про конкретні робочі проблеми розвитку знаменного співу в храмі й за його межами.

3 іншого боку, у сучасній культурі розвиваються різні багатоголосні форми духовного співу. Причому всередині цієї стильової групи піснеспівів відбуваються процеси, спрямовані на досягнення зовсім різних, навіть протилежних цілей.

3 одного боку, це кліросні, уживані за богослужінням піснеспіви, які, у свою чергу, можуть бути класифіковані дихотомічно. По-перше, це група п'єс, у яких суворо дотримується традиція, що створена в попередній церковно-співочій практиці. До них можна зарахувати ті піснеспіви, які створювалися «храмовими» композиторами, такими як архімандрит Матфей (Мормиль), диякон Сергій Трубачов, І. Денісова (мон. Іуліанія) та інші. По-друге, це група піснеспівів, у якій спостерігається помітне відновлення засобів музичної композиції, але 3 неодмінним суворим дотримуванням канону. У цих творах досить яскраво виражене авторське «Я», що дає змогу композиторові донести своє бачення та свої почуття, зберігаючи при цьому загальну спрямованість на дотримання певних правил жанру. До цієї групи можна зарахувати окремі роботи І. Денісової (мон. Іуліаніі), В. Мартинова, В. Польової, О. Юнек, В. Файнера та багатьох інших.

3 іншого боку, це духовна музика, генетично пов'язана з храмовим, богослужбовим співом, але розрахована на концертне виконання, а не на виконання під час відправи богослужіння. Ця група, мабуть, виражена найбільш повно. Варто зазначити, що в ній також спостерігається поділ на два магістральні напрями, а саме: духовні пісні, в основі яких лежать тексти, пов'язані з богослужінням, із релігійним життям, але які не є канонічними. Початок цьому напряму покладено ще наприкінці XIX - початку XX століть у творчості багатьох видатних композиторів, таких як П. Чайковський («Покаянна молитва про Русь»), С. Танєєв («Іоанн Дамаскин», «По прочитанні псалма»), М. Черепнін («Ходіння по муках Богородиці»), О. Кастальський («Братське поминання»). Рубіж XX-XXI століть продовжив цю лінію, у тому числі й у творчості українських композиторів, таких як С. Станкович («Панахида за померлими від голоду» на слова Д. Павличка для читця, солістів, хору й симфонічного оркестру), В. Полева («Покаянні пісні» для змішаного хору a capella), М. Карминський («Поминальний плач»).

Іншим напрямом у сучасній духовній музиці стає низка творів на канонічний текст, але які не призначені для виконання в храмі. Аналогів иьому явищу немає, воно $\epsilon$ історично безпрецедентно, тому що використання канонічного тексту в мирському творі було заборонено й 
суворо контролювалося цензурним комітетом Синоду. Сьогодні ж можна назвати низку творів у тому числі українських композиторів, у яких сполучається канонічний текст із позахрамовою концертною спрямованістю твору, наприклад, цикл «Три духовних пісні», у складі якого «Свете Тихий», «Царице моя преблага», «Вірую» Л. Панкратова; «Царю Небесний», «Боже очисти мя грешнаго» В. Григоренко; «Панахида» I. Соневицького; «Реквієм» для солістів, хору й оркестру О. Карамазова; «Cantus aeternus» для змішаного хору a capella C. Луневой; «Dies irae» для змішаного хору М. Шуха, «Вірші покаянні» А. Шнітке, «Покаянний канон» А. Пярта, Псалом 50 Вікторії Полевої, багато інших.

Отже, духовна музична культура демонструє, 3 одного боку, бажання відновити втрачене, «припасти до джерел», а 3 іншого боку, ніколи ще раніше духовна культура загалом у всіх іiі проявах не була так звернена до особистості в миру. Наприклад, у сучасній пресі з'являється маса літератури, у якій порушуються серйозні богословські питання, однак вона звернена більшою мірою не до церковного духовенства, а до простих мирян. У духовній музиці - це поява великого шару творів на канонічні тексти, але спрямованих на світське виконання. Здається, що подібні явища стають своєрідною відповіддю культури на проблеми особистісної свідомості, на труднощі, що зростають, самопізнання й самооцінки для сучасної людини.

Загалом досвід духовної музичної культури демонструє активну взаємодію двох іiі головних тенденцій, які, відповідно до теорії та термінології М.Бахтіна, можуть бути визначені як охоронномеморіальна й фамільярно-мнемонічна. Виникнення творів, які перебувають на границі між храмовою й світською традиціями, породило формування двох значних тенденцій у музиці кінця XIX початку XX століття, які можуть бути визначені як репродуктивна та креативна, $\epsilon$ вираженням охоронно-меморіальної й фамільярномнемонічної установок культурної пам'яті. Про це свідчив й С. Аверинцев, коли говорив, що культова опозиція «життєвопрофанного й сакрально-табуйованого» $\epsilon$ «споконвічною» та характерною для будь-якого виду духовної творчості.

Ці тенденції як магістральні в процесі формування художньої свідомості й супутніх їй жанрових форм вираження визначені в роботі М. Бахтіна «Епос і роман» ${ }^{21}$. Так, М. Бахтін виділив три «конститутивні риси», що відокремлюють епопею (охоронно-меморіальну тенденцію) від роману (фамільярно-мнемонічної тенденції):

${ }^{21}$ Бахтин М. Эпос и роман. М. Бахтин. Вопросы литературы и эстетики. Исследования разных лет. Москва : Художественная литература, 1975. С. 447-484. 
1) предметом епопеї слугує національне епічне минуле - як «абсолютне минуле». Предметом охоронно-меморіальної тенденції в галузі богослужбового співу стають православна догматика та есхатологія, те, що ми можемо назвати «абсолютним минулим», яке не підлягає переоцінці значеннєвим тезаурусом християнського світогляду;

2) джерелом епопеї слугує національне передання (а не особистий досвід і вільний вимисел, що виростає на його основі). Як джерело охоронно-меморіальної тенденції ми знаходимо церковне Передання, узагальнений соборний досвід, «церковність» у розумінні о. П. Флоренського;

3) епічний мир відділений від сучасності, тобто від часу співака (автора і його слухачів), є абсолютною ціннісною дистанцією. I в охоронно-меморіальній тенденції ми також спостерігаємо «абсолютне дистанціювання», подібно епопеї, що ніколи не була поемою про сьогодення, про свій час. Як епопея із самого початку була «поемою про минуле», так й охоронно-меморіальна тенденція спрямована на «Глибинну пам'ять» 22 .

Творець піснеспівів і їх слухач, «іманентні» охоронно-меморіальній жанровій тенденції, перебувають в одному часі та на одному ціннісному (ієрархічному) рівні, але зображуваний ними мир стоїть на зовсім іншому, недосяжному ціннісно-часовому рівні. Зображувати або трактувати текст на одному ціннісно-часовому рівні із самим собою й зі своїми сучасниками, тобто на основі особистого досвіду, значить зробити радикальний переворот, переступити 3 епічного миру в романний, тобто перейти від охоронно-меморіальної тенденції до фамільярно-мнемонічної.

При розгляді фамільярно-мнемонічної тенденції ми можемо, грунтуючись на характеристиці М. Бахтіна жанру роману, виділити три іiі основних особливості:

1) стилістичну об'ємність, багатомірність цієї тенденції, що зумовлена багатомовністю культурного досвіду, отже, полісемантикою свідомості, відбитою в цьому творі. Як справедливо відзначав М. Бахтін, багатомовність більш давніше канонічного та чистого одномовлення, хоча довгий час воно не було творчим фактором, художньо-навмисний вибір його не був творчим центром. «Мови

22 Бахтин М. Эпос и роман. М. Бахтин. Вопросы литературы и эстетики. Исследования разных лет. Москва : Художественная литература, 1975. С. 456. 
взаємоосвітлюються; адже одна мова може побачити себе тільки у світлі іншої мови» ${ }^{23}$;

2) докорінна зміна тимчасових координат художнього образу, зникнення дистанціювання; мир образів уже не відгороджений «абсолютною епічною дистанцісю»;

3) формування нової зони побудови образу, а саме зони максимального контакту із сьогоденням (сучасністю) у його незавершеності. Мнемонічна тенденція пов'язана із сучасністю, зі «стихією неофіційного слова та неофіційної думки» (М. Бахтін), такою як «фамільярна мова» ${ }^{24}$.

\section{ВИСНОВКИ}

Отже, охоронно-меморіальна тенденція в богослужбово-співацькій традиції апелює не до «реального відносного минулого», а до «ціннісного минулого початків і вершин», звернена до далевого плану пам'яті. Але це не означає, що охоронно-меморіальна тенденція застигла в незмінності, у ній $є$ рух, зумовлений внутрішніми потребами культу.

Так, до піснеспівів, які можуть визначатися як частина охоронномеморіальної галузі, ми можемо зарахувати не тільки всі повсякденні зразки, а й деяку частину ужитково-авторських. Фамільярномнемонічна тенденція функціонує в новій зоні побудови образів у максимальному зближенні «із сьогоденням у його незавершеності, а отже, і з майбутнім» (М. Бахтін). 3 іï допомогою в богослужбовоспівацькій традиції відбувається переломлення й осмислення основних тем поминання, пам'яті в особистому досвіді як важливої активної, навіть ініиіюючої, частини соборної свідомості. Це знаходить своє відбиття в авторському напрямі літургійної, у томі числі й поминальної, музики, у формуванні нових жанрових утворень, які відкривають нову сторінку в композиторській духовній творчості початку XX і початку XXI століть.

Отже, православне співацьке мистецтво можна розглянути як особливий музичний феномен, що виявляє історично перехідну природу; особливо треба підкреслити, що найбільший інтерес до символічних аспектів культової співацької традиції виникає саме в перехідні епохи, коли смисловий зміст людського життя, відповідно до нього, жанрово-стильовий зміст музики (мистецтва), переживає кризу.

Можна визначити, що в українській музиці другої половини XX століття - початку XXI століття поширюються стильові прообрази і

23 Бахтин М. Эпос и роман. М. Бахтин. Вопросы литературы и эстетики. Исследования разных лет. Москва : Художественная литература, 1975. С. 455.

${ }^{24}$ Там само. С. 454-455. 
стилістичні «емблеми» тих хорових жанрів, що, з одного боку, виникли як перехідні, 3 особливою метою зв'язати, призвести до взаєморозуміння протилежні за характером історичні епохи, з іншого боку, стали важливими носіями національних ознак музичного стилю, тому здатні впроваджувати ідею духовності в контекст проблем національної свідомості, створювати власний музично-стильовий контекст для взаємопереходу загальноестетичних уявлень про духовне й особливих національних умов його інтерпретації.

\section{АНОТАЦІЯ}

Актуальність обраного напряму музикознавчого дослідження зумовлюється місцем, становищем і значенням православної культури, отже, значенням релігійного співу, що входить в неї, - того, що 3 відомою мірою умовності можна назвати релігійною музикою в іiі відносинах із сучасним соціокультурним простором. Водночас множинність форм духовного життя актуалізує проблему православної християнської традиції, пов'язаної 3 перевіреними історичною практикою канонами як релігійного, так i художнього мислення. У зв'язку з цим виникає необхідність в уточненні історичної оцінки церковного співу, у поглибленні розуміння природи і змісту духовної музики.

Зв'язана певним чином 3 актуальними принципами гуманітарної системи, релігійно-храмова культура як духовно-канонічна виявляє історично рухливу природу; особливо підкреслимо, що ії значення, як і значення символічних аспектів людської творчості, підсилюється саме в перехідні епохи, коли смисловий зміст людського життя, відповідно до нього, жанрово-стильовий зміст музики (мистецтва), переживає кризу, за якою дуже часто таїться ініціативне прагнення культури до нових духовних цінностей i до нових способів ремінісценції попередніх.

Виявляється, що вже із середини XIX століття в хоровій вітчизняній музиці окреслюються дві рівнозначні жанрові тенденції. Перша з них зв'язана з розвитком традиційного службового (храмового) співу, зі збереженням і зростанням інтересу до культової хорової музики як до найбільш давньої і тривалої традиції національного мистецтва. Друга тенденція означає нові уявлення про можливості хорової музики - уже за межами культової практики й у зв'язку з усім досвідом світської композиторської творчості означає нове ставлення до жанровосемантичних можливостей хорової музики, починає вимагати окремої форми, автономних композиційних рішень. 


\section{SUMMARY}

The state of modern culture, as well as the state of modern humanities knowledge, necessitates the discussion of a number of issues related to modern artistic manifestations and the definition of the status of Orthodox singing. Both for traditional art and musicological literature, and for theological research, such a perspective of study, and the associated conceptual complex, still remains new, little mastered. A similar situation arises in the direct systematic assimilation of this tradition as an academic discipline, because it exists in the gap between the religious and secular spheres of knowledge; it is partially initiated by each of them, but does not belong to any of them to the end. Thus, at the first stage of its formation, the phenomenon of Orthodox singing art reveals the transience, as well as the existence of different, multiple approaches to it.

The relevance of this area of musicological research is determined by the place, position and importance of Orthodox culture, and therefore the importance of religious singing, what it includes - what with some degree of conventionality can be called religious music in its relationship with modern socio-cultural space. At the same time, the multiplicity of forms of spiritual life actualizes the problem of the Orthodox Christian tradition, associated with the canons of both religious and artistic thinking, tested by historical practice. In this regard, there is a need to clarify the historical assessment of church singing, to deepen the understanding of the nature and content of spiritual music.

A separate issue is the entry of Orthodox singing into the musical culture, so, the extent to which the Orthodox liturgical tradition can be considered as part of musical culture. This means that the subject of attention is the musical culture itself - as a category that can be filled with different conceptual meanings, interpretations of these meanings. On the other hand, Orthodox singing is a historically and structurally and semantically completed holistic cultural phenomenon that reproduces and develops the dominant moral and aesthetic tendencies of culture.

The beginning of the development of Christian Orthodox worship and the associated formation of a special corpus of texts, the development of the ceremonial side of worship is associated with the activities of Emperor Constantine the Great, because it was during his reign, according to the Edict of Milan (313), when Christianity became official state religion. From this moment begins the active development of all kinds of church arts, the construction of majestic churches, the improvement of liturgical rites, the emergence of a significant number of new prayer texts and a strong impetus to the development of liturgical singing. The basic principles of Christian culture in its fullest form were formed in Byzantium, which found their expression in Byzantine art. 
In this regard, it would be difficult to deny the profound changes that marked the liturgical life of the Church since the time of Constantine, however, in many historical studies, for example according to Fr. Alexander Schmemann, numerous explanations of what this change was, were often incorrect or incomplete because they came from the wrong historical perspective. They reflected the limitations of the method of studying the history of worship, which Fr. Alexander Schmemann defined it as "liturgical formalism". This method, according to Schmemann, reduces the whole study of the history of worship to the analysis of liturgical texts, to the classification of various "liturgical families" and their subdivisions, to the study of their influence on each other, and so on.

In other words, the objective meaning of religion, which we can find in its "official" expressions (dogmas, cults, etc.), may be understood and experienced by the religious community of each era in a different way depending on its various cultural, spiritual and social features.

This "refractive index" (Schmemann) defines "religiosity", or religious feeling, and the latter, in turn, affects the further development of "religion" in its objective sense.

Especially significant and important in the study of the evolution of Christian singing is the above-mentioned immanent quality of the singing side of worship, due to which this religious feeling is most clearly expressed. Schmemann defines this religiosity or religious feeling as liturgical piety, and Fr. Paul Florensky defines a person who has similar qualities as a "liturgical person". Thus, the "refractive index" is the psychological perception of a cult, its experience in a religious feeling, its refraction in the minds of believers.

One of the dominant trends in the culture of the late XIX - early XX and late $\mathrm{XX}$ - early XX centuries, which brings together these epochs in great historical time, is the desire to rethink many social, including religious values. At the turn of XX-XXI, the dialogical interaction of secular ("profane") and religious, ecclesiastical ("sacred") types of consciousness becomes even more active, but rather with the "logic of reversibility"; in connection with the new popularity and social engagement of religious and even liturgical themes in secular art, it becomes possible to lose the symbolism as the "warmth of a cohesive secret" (S. Averintsev), which should be an integral part of everything related to worship.

Disclosure of this problem of the current state of church art, its style definitions is extremely important for understanding the current state of Orthodox culture in the world, but is associated with a wide range of studies of church and secular types of cultural consciousness from early Christianity to the present day. On the other hand, it is the experience of musical creativity that allows us to highlight the key points of this problem and show productive ways to solve it. 
The problem of preserving and transmitting spiritual experience - as an experience of creating a valuable foundation of culture - in the sense of semantic self-determination and a kind of "justification" of human existence is becoming one of the central and most in demand at the present stage. In this regard, all kinds of Orthodox liturgical singing, their revival and "new life" in the modern compositional and performing environment, as well as a marked intensification of the musical and singing life of the Orthodox Church are of great interest. However, research related to a systematic approach to both the liturgical-singing tradition and to the religious-church culture in general, especially in its historical dynamics and in the simultaneous socio-aesthetic dimension, is still clearly insufficient. Therefore, the involvement of theoretical generalizations of leading humanitarian figures in the study of traditional church culture acquires special significance, among which the works of M. Bakhtin become important, which makes it possible to determine the style orientation of the analyzed material.

Today, the topic of style foundations of Orthodox culture, including singing, has become so relevant that it has created an extraordinary diversity, eclecticism in the assessment of this phenomenon. Although, in fairness, it must be said that the singing culture of the Orthodox Church in the early XX century caused not less controversy and polemics. But it should be noted that the liturgical singing of the early XX century and late XX century is cultural phenomena that are markedly different, although related to the common musical and intonation sources, the "memory" of the genre.

\section{ЛІТЕРАТУРА}

1. Аверинцев С. Поэтика ранневизантийской литературы. СанктПетербург : Азбука-классика, 2004. 480 с.

2. Архимандрит Киприан (Керн). Литургика. Гимнография и эортология. Москва : Крутицкое Патриаршее Подворье, 1999. 152 с.

3. Бахтин М. Эпос и роман. М. Бахтин. Вопросы литературы и эстетики. Исследования разных лет. Москва : Художественная литература, 1975. С. 447-484.

4. Гарднер И. Богослужебное пение Русской Православной Церкви. Сущность. Система. История. Сергиев Посад : Московская духовная академия, 1998. Т. 1.592 с.

5. Гарднер И. Богослужебное пение Русской Православной Церкви. История. Сергиев Посад : Московская духовная академия, 1998. T. II. $640 \mathrm{c}$.

6. Добротолюбие избранное для мирян. Москва : Изд. Сретенского монастыря, 2010. 352 с. 
7. Епископ Каллист (Уэр). Внутренний смысл Предания. Предание и Церковь: от смысла к вечности. Роль Священного Предания в Православной Церкви / сост. А. Баранов. Москва : Образ, 2007. 128 с.

8. Кутузов Б. Возрождать ли нам знаменный распев? Журнал Московской Патриархии. 1993. № 3. С. 69-71.

9. Лихачев Д. Поэтика древнерусской литературы. Москва : Наука, $1979.360 \mathrm{c}$.

10. Лосский В. Предание и предания. Журнал московской nатриархии. 1970. № 4. С. 61-76.

11. Мартынов В. История богослужебного пения : учебное пособие. Москва : РИО Федеральных архивов; Русские огни, 1994. 240 с.

12. Матвеев Н.В. Хоровое пение. История русского церковного пения. Электросталь : Издательство братства во имя святого князя Александра Невского, 1998. 287 с.

13. Никольский А. Краткий очерк истории церковного пения в период I-X веков. О иерковном пении : сборник статей. Москва : Лодья, 2001. С. 27-62.

14. Никольский А. П.И. Чайковский как духовный композитор. Музыкальная жизнь. Москва, 1990. № 9. С. 14-29.

15. О. Александр Шмеман. Введение в литургическое богословие. Санкт-Петербург : Библиополис, 2006. 440 с.

16. Преображенский А. Культовая музыка в России. Русская духовная музыка в документах и материалах. Церковное пение пореформенной России в осмыслении современников (1861-1918). Москва : Языки русской культуры, 2002. Т. 3. С. 656-675.

17. Св. Василий Великий. Творения. Полное собрание творений Святых Отияв Церкви. Николаев : Сибирская Благозвонница, 2010. T. $2.1232 \mathrm{c}$.

18. Трубин Н. Духовная музыка. Смоленск : Смоленское областное книжное издательство «Смядынь», 2004. 229 с.

19. Успенский Н. Древнерусское певческое искусство. Москва: Музыка, 1965. $216 \mathrm{c.}$

20. Чайковский П. Письмо ректору Киевской духовной академии о состоянии церковного пения. 1882. URL: www.penie.mrezha.ru/ pismochaj.

21. Wellesz E. A histori of Byzantine music and himnografhy. Oxford : At the Clarendon press, 1949. $358 \mathrm{p}$.

\section{Information about the author: Osadcha S. V.,} Doctor of Arts, Professor,

Head of the Department of Music History and Musical Ethnography Odessa National A. V. Nezhdanova Academy of Music 63, Novoselskogo str., Odessa, Ukraine 